\title{
Daily growth patterns of juveniles and adults of the Peruvian anchovy (Engraulis ringens) in northern Chile
}

\author{
Francisco Cerna ${ }^{\mathrm{A}, \mathrm{C}}$ and Guido Plaza ${ }^{\mathrm{B}}$ \\ A División de Investigación Pesquera, Instituto de Fomento Pesquero, Avenue Blanco \\ Encalada 839, PO Box 8V, Valparaíso, Chile. \\ ${ }^{B}$ Escuela de Ciencias del Mar, Pontificia Universidad Católica de Valparaıíso, \\ Avenue Altamirano 1480, Valparaiso, Chile. \\ ${ }^{\mathrm{C}}$ Corresponding author. Email:francisco.cerna@ifop.cl
}

\begin{abstract}
The Peruvian anchovy (Engraulis ringens) is a resource of considerable economic importance, whose stock unit is distributed between $16^{\circ} 00^{\prime} \mathrm{S}$ and $24^{\circ} 00^{\prime} \mathrm{S}$ and is shared between Chile and Peru. In the present study, daily growth patterns of juvenile and adult Peruvian anchovies in northern Chile were determined using micro-increments of sagittal otoliths for the recruitment and fishery seasons of 2009 and 2010. A characteristic feature was the existence of very distinctive daily micro-increments, through which a complete sequence of micro-increments was obtained from the primordium to otolith edge for juveniles (7.5-12-cm total length (TL)) and adults (12.5-18.0 cm TL), whose ages were in the range 56-166 and 137-409 days respectively. Hatch dates extended from July 2009 to July 2010, where juveniles recruited to a fishery in a given month were the survivors of a spawning that had occurred approximately 3-4 months before. A Laird-Gompertz model fitted to length-at-age data for juveniles estimated maximum instantaneous growth rates that ranged from 0.98 to $1.57 \mathrm{~mm}_{\text {day }}{ }^{-1}$, whereas overall mean individual growth rates back-calculated for the age range of juveniles ranged from 0.65 to $1.02 \mathrm{~mm}_{\text {day }}{ }^{-1}$. The von Bertalanffy seasonal parameters estimated through the entire life history showed high growth, with a growth coefficient $K=1.1$ and mean length at the first year of $16.3 \mathrm{~cm}$ TL. Consequently, E. ringens in northern Chile seems to maximize growth in the first year of life.
\end{abstract}

Additional keywords: growth parameters, sagittae otolith.

Received 25 January 2015, accepted 7 January 2016, published online 20 April 2016

\section{Introduction}

Fish age determination and growth is very important in population dynamics of fisheries because it improves analysis of temporal variations in structure and abundance (Casselman 1990; Panfili et al. 2002). For example, the age structure of the population can be described, and rates of key processes, such as growth, recruitment and mortality, can be quantified. Hence, age- and length-based parameters are very useful in structural models that consider the structure of the stock by age and the evolution of the structure with time (Summerfelt and Hall 1987; Panfili et al. 2002). These models primarily recognise that the stock is composed of individuals of different cohorts and, consequently, of different ages and sizes. So, they analyse and project the stock and catches for coming years by following the evolution of the different cohorts (Beamish and McFarlane 1987; Sparre et al. 1998; Casselman 1990; Panfili et al. 2002). Therefore, age-structured population analysis is incorporated in classic fish stock assessment models, mathematical tools that form the preferred basis of scientific advice regarding fishery resources worldwide (Panfili et al. 2002).
The Peruvian anchovy (Engraulis ringens) plays a key ecological role in the Humboldt Current System (HCS) because it is the major prey of predators such as fish, marine mammals and sea birds and so is essential for the maintenance of the integrity of this ecosystem (Espinoza and Bertrand 2008; Ludynia et al. 2010). This species is distributed from northern Peru $\left(4^{\circ} 30^{\prime} \mathrm{S}\right)$ to southern Chile $\left(42^{\circ} 30^{\prime} \mathrm{S}\right)$, where two main large stocks have been identified: one in the northern-central area of Peru and the other in southern Peru and northern Chile (Pauly and Tsukayama 1987). The latter stock population supports important fishery activity throughout its distribution (i.e. $16^{\circ} 00^{\prime}-24^{\circ} 00^{\prime} \mathrm{S}$ ), representing a substantial fraction of global anchovy fisheries (Bakun and Weeks 2008; Aranda 2009; Schreiber and Halliday 2013). In northern Chile, the fishery is located between $18^{\circ} 21^{\prime}$ and $24^{\circ} \mathrm{S}$, and is managed on the basis of total allowable catches (TAC) and reproductive and recruitment closing periods. TACs are based on age-structured stock assessment models on the basis of the calendar year; however, in recent years it has been necessary to change the age composition of catches by using the biological year to properly 
include the result of the long reproductive period of this species, which extends from June to February (winter to summer; Claramunt et al. 2012). Such a protracted reproductive period triggers continuous recruitment to the fishery throughout the year in both the Peruvian and Chilean fisheries.

The existence of a protracted reproductive season intrinsically implies that somatic growth during the first year of life of this species would vary with the seasonality of growth controllers (i.e. temperature and productivity). Such a scenario would affect the readability of the first annuli, because the first hyaline rings, associated with the slow growth period, would form at different stages of development, depending upon the hatching month. Indeed, to date, the reliability of otolith annuli readings remains contentious for this species. A macroscopic study of sagittae otoliths in coastal waters of Peru indicated the formation of two hyaline rings per year (Chirinos and Chumán 1968). Aguayo (1976) also indicated, through edge analysis, the formation of two hyaline rings per year, one in winter with maximum frequency in July and another in spring. Chirinos and Chumán (1968) suggested the formation of the second ring could be associated with gonadal development, although without a decrease in somatic growth because of the high productivity of the HCS. Subsequently, through microincrement and edge analyses of otoliths, a study in southern Peru suggested that this species would form an annual hyaline band in November and December Morales-Nin (1989). In contrast, for other species of anchovy, such as Engraulis mordax (Baja California, Mexico; Gallardo-Cabello 1985) and Engraulis encrasicolus (Spain; Cermeño et al. 2003), the formation of one hyaline ring per year has been reported, but in the winter period.

The uncertainty associated with annuli reading would trigger significant errors in the catch-at-age matrix, and consequently affect the determination of stock levels. However, as yet there has been no comprehensive analysis of otolith microstructure in juvenile and adult fish of this species. In this context, it is important to emphasise that the method of counting otolith micro-increments is considered the most reliable method for ageing short-lived species (Geffen 1982; Waldron 1994; Campana 2001). Hence, it seems mandatory to incorporate otolith micro-structure analysis to evaluate the reliability of annuli formation in this species. To contribute to filling this gap in the knowledge, the aim of the present study was to characterise the daily growth patterns of juvenile and adult Peruvian anchovy (Engraulis ringens) in northern Chile using analysis of daily micro-increments of sagittal otoliths for the recruitment and fishery seasons of 2009 and 2010.

\section{Materials and methods}

\section{Sampling and otolith preparation}

Immature and mature adults anchovies were collected in northern Chile on board pair seine fishery vessels and hydroacoustic surveys from November 2009 to October 2010 between $18^{\circ} 21^{\prime}$ and $24^{\circ} 00^{\prime} \mathrm{S}$ (Fig. 1; Table 1). On board, total length (TL) was measured to the nearest $0.01 \mathrm{~mm}$, and then the left and right sagittae were removed, cleaned of adhering tissue, dried and stored for subsequent analysis. Sagittae from both juveniles and adults were mounted in epoxy resin on glass slides and polished

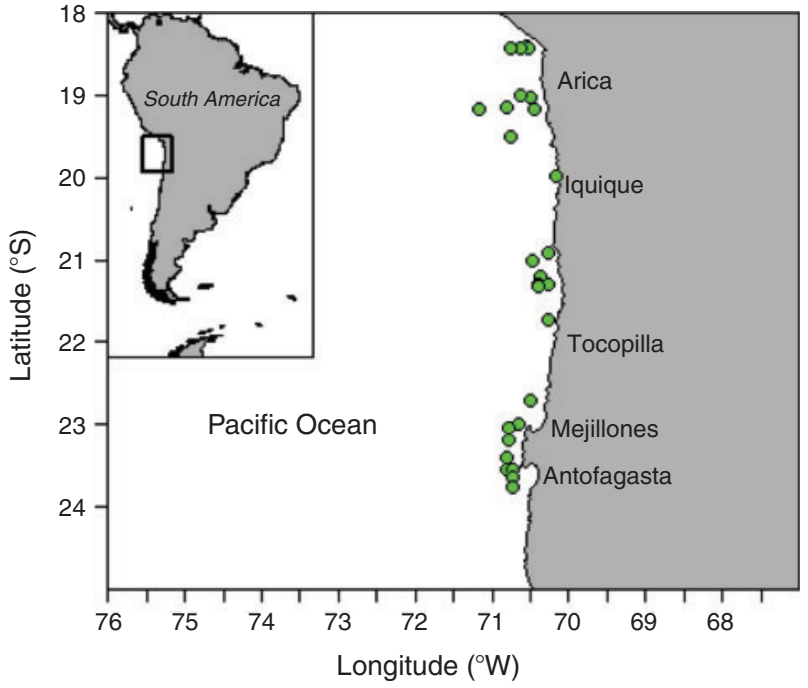

Fig. 1. Fishing area for the Peruvian anchovy (Engraulis ringens) in northern Chile. Dots indicate the location where fish where collected.

in the sagittal position for examination of primary increments using the slide-glass-embed-method (SGEM; Plaza et al. 2005). A single side was polished until the core area of sagittae was reached in juveniles $<8 \mathrm{~cm}$ TL, whereas a two sides were polished to reach the core in juveniles between 8 and $12 \mathrm{~cm}$ TL. Because of a slight concavity of the sagittae of adults $>12 \mathrm{~cm}$ $\mathrm{TL}$, serial polishing was used to get a complete sequence of primary micro-increments.

\section{Age determination}

After obtaining a thin section, micro-increments were counted from a prominent concentric check surrounding the primordium, which is formed 3 days after hatching in this species (Castro and Hernández 2000). Primary micro-increments (PM) were identified as two successive incremental (light. L) and matrix-rich (dark, D) zones (Pannella 1971; Campana 1992). In some areas of the otoliths, subdaily and double rings encompassed wider micro-increments and these were counted as PMs (Fig. 2) following the criteria of Plaza and Cerna (2015), which consisted of applying the bipartite reading criterion (BRC), where each micro-increment comprising a double structure was quantified as a single ring. All counting and measurements of PMs were performed twice for each otolith by two independent readers using the 'manual tag' 'calliper' tools available in the software image analysis program Image-Pro Plus (Media Cybernetics, Inc., Bethesda, MD, USA) at magnifications of $400 \times$ and $1000 \times$. In all cases, more than one photograph was taken and combined to obtain the complete sequence of microincrements from the core to the otolith edge before being counted and measured.

In the case of juveniles $\leq 12 \mathrm{~cm}$ TL the daily microincrements were counted and measured thorough the dorsal axis where subdaily micro-increments were less frequent. In adult fish, micro-increments could not be measured because it was not possible to obtain a unique axis through which daily micro-increments could be reliably measured. However, daily 
Table 1. General statistics of total length $(\mathrm{cm})$ and daily age of 351 juveniles and 107 adults Engraulis ringens, collected in northern Chile from October 2009 to November 2010, grouped by sampling month

Missing months in the table are the result of the absence of data. s.d., standard deviation

\begin{tabular}{|c|c|c|c|c|c|}
\hline \multirow[t]{2}{*}{ Sampling month } & \multicolumn{2}{|c|}{ Total length $(\mathrm{cm})$} & \multicolumn{2}{|c|}{ Age (days) } & \multirow{2}{*}{$\begin{array}{c}\text { Number of fish } \\
\text { analysed }\end{array}$} \\
\hline & Mean \pm s.d. & Range & Mean \pm s.d. & Range & \\
\hline \multicolumn{6}{|l|}{ Juvenile } \\
\hline November & $9.7 \pm 1.0$ & $9.0-12.0$ & $82 \pm 15$ & $60-127$ & 32 \\
\hline December & $8.7 \pm 1.5$ & $9.5-12.0$ & $85 \pm 22$ & $64-148$ & 39 \\
\hline January & $10.2 \pm 0.8$ & $9.5-12.0$ & $108 \pm 12$ & $70-130$ & 41 \\
\hline February & $10.9 \pm 0.6$ & $8.5-12.0$ & $126 \pm 24$ & $64-168$ & 42 \\
\hline April & $10.7 \pm 0.9$ & $11.0-12.0$ & $100 \pm 16$ & $64-130$ & 60 \\
\hline May & $11.2 \pm 0.5$ & $9.5-12.0$ & $123 \pm 14$ & $94-169$ & 42 \\
\hline June & $11.3 \pm 0.3$ & $11.0-11.5$ & $111 \pm 7$ & $103-122$ & 9 \\
\hline July & $11.3 \pm 0.5$ & $10.0-11.5$ & $146 \pm 15$ & $117-178$ & 19 \\
\hline September & $11.4 \pm 0.3$ & $8.0-11.5$ & $126 \pm 14$ & $112-142$ & 4 \\
\hline October & $10.4 \pm 0.3$ & $7.5-11.5$ & $133 \pm 20$ & $101-173$ & 27 \\
\hline Annual & $10.4 \pm 1.1$ & $7.5-12.0$ & $111 \pm 26$ & $60-178$ & 351 \\
\hline January & $14.2 \pm 0.9$ & $12.5-16.0$ & $239 \pm 26$ & $190-312$ & 28 \\
\hline March & $13.2 \pm 0.8$ & $12.5-14.5$ & $216 \pm 33$ & $181-255$ & 5 \\
\hline April & $13.9 \pm 1.1$ & $12.5-15.5$ & $239 \pm 61$ & $148-346$ & 19 \\
\hline May & $13.4 \pm 1.0$ & $12.5-16.0$ & $254 \pm 46$ & $137-343$ & 43 \\
\hline June & $15.5 \pm 0.7$ & $15.0-16.0$ & $248 \pm 40$ & $219-276$ & 2 \\
\hline July & $16.6 \pm 0.6$ & $16.0-17.5$ & $347 \pm 48$ & $265-409$ & 7 \\
\hline September & $17.5 \pm 0.7$ & $17.0-18.0$ & $343 \pm 49$ & $308-378$ & 2 \\
\hline November & $12.5 \pm 0.0$ & $12.5-12.5$ & $148 \pm 0$ & $148-148$ & 1 \\
\hline Annual & $14.0 \pm 1.3$ & $12.5-18.0$ & $252 \pm 53$ & $137-409$ & 107 \\
\hline
\end{tabular}

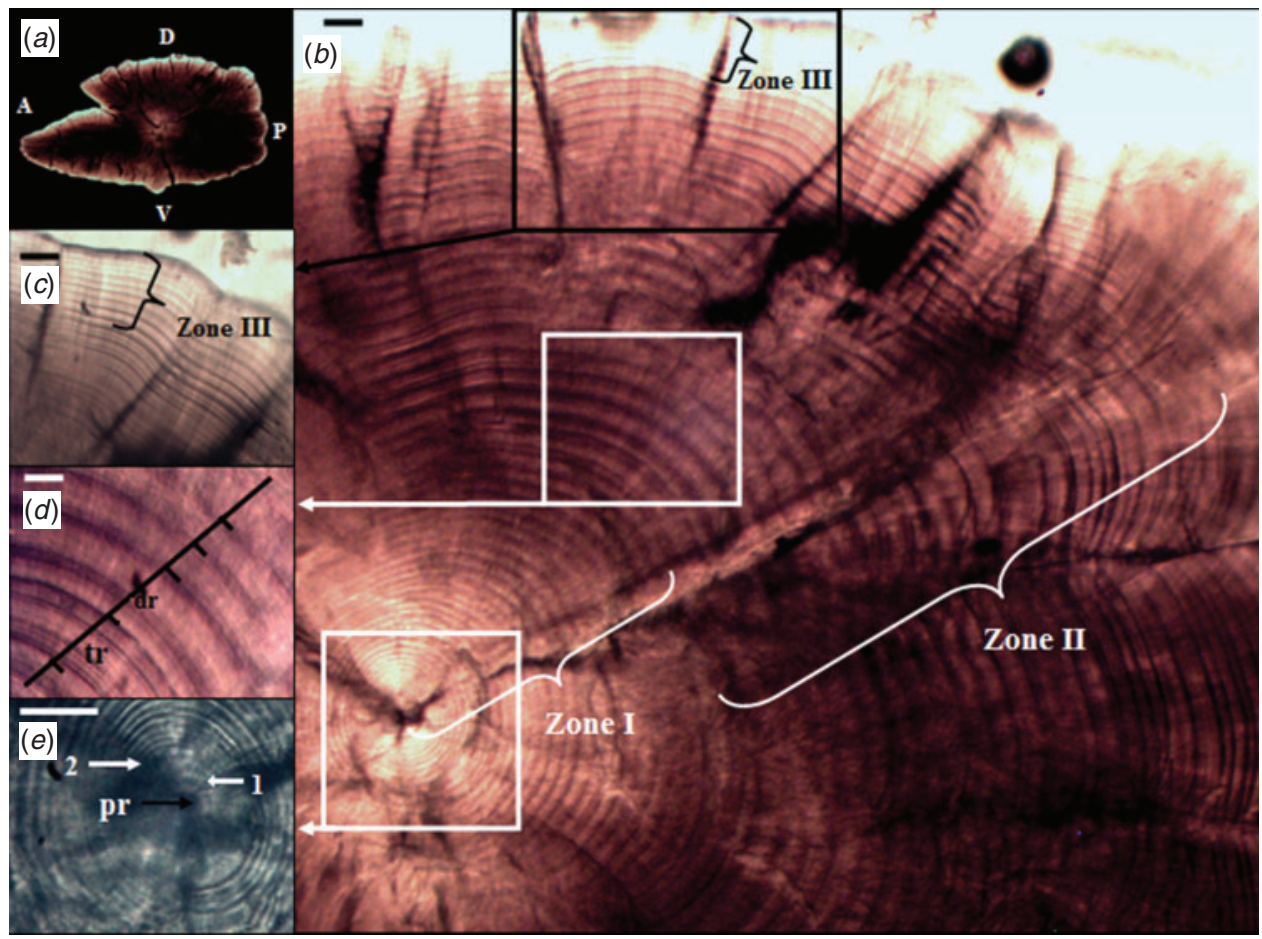

Fig. 2. Photographs showing microstructural features of a left sagitta from a juvenile Engraulis ringens (10-cm total length) collected in northern Chile. (a) Entire sagitta at an original magnification of $100 \times$. D, dorsal; $\mathrm{V}$, ventral; P, posterior; A, anterior. (b) Image at an original magnification of $400 \times$ showing the otolith zones. $(c-e)$ Enlarged images taken close to the otolith edge in Zone III $(c)$, Zone II $(d)$ and close to the otolith core $(e)$. The black marks in $(d)$ denote the reading criteria. tr, triple rings; dr, double rings; pr, primordium; 1 , hatch check; 2, first feeding check. Scale bars: $10 \mu \mathrm{m}$. 
increments were counted through the dorsal axis up to approximately the first 50 days and then moved to the antirostral axis until the otolith edge. PMs close to both the core and the otolith edge of adult fish were counted using images taken at $1000 \times$ magnification. The total age of juveniles and adults was determined on the basis of mean counts of PMs from two replicates (made by the two independent readers); when counts differed by more than $5 \%$, the sample was rejected.

The number of PMs was regarded as daily age because the daily periodicity of increment formation was validated in juveniles (5-6 cm TL) and adults (13-16 cm TL) for this species by Plaza and Cerna (2015) through a rearing experiment where fish were exposed to marking immersion treatments with alizarin red $\mathrm{S}$ and oxytetracycline hydrochloride. The relationship between the number of micro-increments between fluorescent marks and the number of elapsed days indicated that there was a significant correspondence between the number of increases observed and the number of days. Three days were added to the total age because this species forms the first micro-increments 3 days after hatching (Castro and Hernández 2000). Hatch dates (HD) of larvae were back-calculated by subtracting the total age in days from the calendar day of sampling. The distribution of HDs was not corrected for mortality effects because survival rates during the larval stage were not available for the years studied. Hence, HDs were only used to describe the spawning characteristics of adults as related to the growth analysis and recruitment season.

\section{Data analysis}

The age-at-length relationship was first analysed for juvenile fish $\leq 12 \mathrm{~cm}$ TL, which corresponds to mean length-at-maturity for this species (Canales and Leal 2009), because it is very important to provide growth estimates for immature fish using a model whose estimated parameters are comparable with previous studies. The length distribution was shown by month as the mean length \pm s.d. (standard deviation) The Laird-Gompertz model was used because it has been widely used to characterise early growth patterns in members of the Engraulidae family and other teleost fish. The function has three parameters: $L_{\infty}$ is the asymptotic length; $X_{0}$ is the inflexion point of the curve; and $\alpha$ is the instantaneous growth rate at age $X_{0}$ (Campana and Jones 1992).

$$
L_{x}=L_{\infty} \exp \left[-\exp \left(-\alpha\left\{\text { age }-X_{0}\right\}\right)\right]
$$

In this equation, the absolute growth rate $\left(G_{R}\right)$ at any given age is estimated as follows:

$$
G_{R}=\alpha \times L_{x}\left(\ln L_{\infty}-\ln L_{x}\right)
$$

The absolute growth rate at the inflexion $\left(G_{X_{0}}\right)$ point is calculated as:

$$
G_{X_{0}}=\alpha \times L_{X_{0}}\left(\ln L_{\infty}-\ln L_{X_{0}}\right)
$$

where $L_{X_{0}}$ is the estimated length at $X_{0}$.

Furthermore the overall absolute growth rates (AGR) for each fish as follows:

$$
A G R=(T L-e) \div \text { age }
$$

where $T L$ is the total length of the specimen and $e$ is the size at hatching, defined as $2.5 \mathrm{~mm}$ (Llanos-Rivera and Castro 2006).

It is also important to integrate age-at-length information between immature and mature fish. For this purpose, three models were explored: (1) the Laird-Gompertz model (as described above); (2) the traditional von Bertalanffy model (von Bertalanffy 1938); and (3) the seasonal von Bertalanffy model (Somers 1988). Although these three models give estimations of an asymptotic length, they describe allometric, sigmoid and seasonal growth patterns respectively.

The traditional von Bertalanffy model (von Bertalanffy 1938) uses the following equation:

$$
L_{t}=L_{\infty}\left(1-\exp ^{-K\left(t-t_{0}\right)}\right)
$$

where $L_{t}$ is length at age $t, L_{\infty}$ is the asymptotic length, $K$ is the growth coefficient and is proportional to the rate at which a $L_{\infty}$ is reached and $t_{0}$ is the age at which the fish has zero length.

The seasonal von Bertalanffy model (Somers 1988) uses the following equation:

$$
\begin{aligned}
L_{t}= & L_{\infty}\left[1-\exp \left\{-K\left(t-t_{0}\right)-\frac{C K}{2 \pi}\left[\sin \left(2 \pi\left(t-t_{s}\right)\right)\right.\right.\right. \\
& \left.\left.\left.-\sin \left(2 \pi\left(t_{0}-t_{s}\right)\right)\right]\right\}\right]
\end{aligned}
$$

where $t_{S}$ is the time between Time 0 and the start of the convex portion of the first sinusoidal growth oscillation (i.e. the inflection point) and $C$ is a dimensionless constant expressing the amplitude of a growth oscillation. If $C=0$, then there is no seasonal variation and the model reduces to the typical von Bertalanffy growth model. If $C=1$, then growth stops completely once year at the 'winter point' (García-Berthou et al. 2012). All models were fitted using the non-linear routine 'nls' available in the statistical software package $R$ (Ihaka and Gentleman 1996). To choose the best model, the Akaike information criterion (AIC; Akaike 1974) was used as follows:

$$
\text { AIC }=-2(\ln (\text { likelihood }))+2 K
$$

The best model was the one with the lowest AIC. The AIC is a measure of the relative quality of a statistical model for a given set of data compared with alternative models.

\section{Increment width profiles and individual growth rates for juveniles}

In parallel with fitting growth models to length-at-age data at capture date, data of radii-at-age for each fish provided a way to address growth variability as the season progressed by examining mean increment width and mean individual growth rate (IGR) profiles by monthly cohorts. These analyses were only performed for juveniles because increment measurements could not be performed in adults. IGRs were obtained by backcalculation of TL at previous ages using the biological intercept method (BIM; Campana 1990):

$$
L_{T}=L_{c}+\left(R_{i}-R_{c}\right)\left(L_{c}-L_{T h}\right) \div\left(R_{c}-R_{h}\right)
$$


where $L_{T h}$ is the larval size at hatching (i.e. the biological intercept), $R_{h}$ is the otolith radius at the hatch check, $L_{c}$ is the size of the fish at capture, $R_{i}$ is the otolith radius at a previous age and $R_{c}$ is the otolith radius at the time of capture. The daily individual growth rates $\left(G_{I}\right)$ were estimated as follows:

$$
G_{I}=L_{T i+1}-L_{T i}
$$

where $L_{T i+1}$ is the length at time $T i+1$ and $L_{T i}$ is the length at time $T i$. The biological intercept in the present study was set at $2.5 \mathrm{~mm}$ TL, the length at hatching (LH) defined for this species (Llanos-Rivera and Castro 2006). Differences in mean increment width and IGR profiles between monthly cohorts were addressed using univariate repeated-measures analysis of variance (ANOVA; Chambers and Miller 1995). The analysis was a two-factor design, with cohort as an independent factor (i.e. between-subject factor) and increment width or IGR at age as repeated factors. To reduce the elevated numbers of comparisons over age, all repeated-measures ANOVAs were achieved on balanced set of levels over each 5 days from hatch check, but truncated at Day 120 to maximize the number of observations and repeat measures to compare among cohorts. In the case of IGRs, analysis was only performed from Day 50 to Day 120 because back-calculations cannot be performed from juveniles to larvae.

\section{Results}

\section{Otolith micro- and macrostructure}

In general, patterns of formation of micro-increments of juvenile $E$. ringens $\leq 12 \mathrm{~cm}$ TL were very distinctive, showing three micro-structural zones (Zones I, II and III; Fig. 2). The first zone (Zone I) formed immediately after a diffuse area surrounding a central primordium and extended to $\sim 30$ days (Fig. $2 b, e$ ). The increment width in Zone I ranged from 4 to $10 \mu \mathrm{m}(7.4 \pm 1.6 \mu \mathrm{m})$, showing a sequential increase, a regular appearance and almost a complete absence of subdaily microincrements. Zone II, from approximately 30-50 days, was characterised by the presence of wider micro-increments (mean increment width $18.3 \pm 3.1 \mu \mathrm{m}$; range 9-22 $\mu \mathrm{m}$; Fig. $2 b, d$ ). In this zone, the formation pattern was more irregular, with the presence of double and triple rings and other growth discontinuities (Fig. 2d). Towards the edge of the otoliths, Zone III was characterised by a decrease in micro-increment width (Fig. 2b,c).

For fish $>12 \mathrm{~cm} \mathrm{TL}$, it was also possible to identify a complete sequence of primary micro-increments from the primordium to the otolith edge (Fig. $3 a-h$ ). After the primordium and for the first 30 days, micro-increments resembled those found in juvenile otoliths; after this zone, there was a fast growth period began (range of increment width 11-17 $\mu \mathrm{m}$ ) that persisted until approximately Day 60 (Fig. 3d). After this zone, increment width started to decrease gradually towards the otolith edge; however, it was still possible to observe distinctive primary micro-increments (Fig. $3 e-h$ ). Fig. $3 a$ shows an otolith with three hyaline rings identified by surface reading. The range in micro-increment widths inside these structures was 3.5-2.5, $3.3-1.6$ and $2.1-1.2 \mu \mathrm{m}$ from the inner to the outermost hyaline ring in the otolith edge respectively.
The pattern of growth of macrorings in anchovy otoliths consisted of an initial large opaque area, which encompassed $\sim 75 \%$ of the whole otolith. This area was followed by a hyaline area, where it was not possible to clearly identify a regular alternation of hyaline and opaque rings (Fig. $3 a, b$ ). A marked first hyaline ring could be detected in half the opaque area in only a few otoliths. The opaque area was thicker, matching the occurrence of wider micro-increments (Fig. 3d). In the hyaline area, the thin ring, presumably identified as annual rings (annulus), tended to disappear from the macrostructure once the otolith was polished.

\section{Hatch and catch date relationship}

Overall, 351 otoliths from juvenile $E$. ringens collected between November 2009 and October 2010 were analysed; the TL and age ranges of these juveniles were 7.5-12 cm and 56-166 days respectively. Hatch dates extended from July 2009 to July 2010, where juveniles recruited to a fishery in a given month were the survivors of a spawning that had occurred $\sim 3-4$ months before catching (Fig. 4). The results also showed that spawning was distributed almost over the course of an entire year.

\section{Age-length relationships for juvenile fish}

The age-length relationship of all combined samples showed a high variability for length (7.5-12 cm TL) and age (56-166 days) ranges (Fig. $5 a$ ), particularly after the third month of life. However, this relationship was significantly described by a Laird-Gompertz growth model. The model estimated a maximum instantaneous growth rate of $1.57 \mathrm{~mm} \mathrm{day}^{-1}$ to the inflection point of 37 days (Table 2). To assess whether the seasonality of spawning could be affecting the apparent variability in the length-age relationship, a separate analysis for hatched monthly cohorts was performed for September and October, when the size range was sufficient enough to enable an allometric growth pattern to be observed (Fig. $5 b, c$ ). Although there was an improved fit, the estimated instantaneous growth rates were similar to those obtained using the global analysis (Table 2).

\section{Increment width profiles and IGRS}

Mean increment width ranged from 2.87 to $20.58 \mu \mathrm{m}$ varying over age and hatch month $(P<0.05$, repeated-measures ANOVA), showing, regardless of hatch month, an increasing and decreasing tendency, although with a more dome-shaped pattern in winter cohorts, where increment width increased gradually even beyond the second month of life (Fig. 6; Table 3). In the rest of the cohorts, accelerated growth occurred for the first 30-40 days, where increment width peaked at $\sim 20 \mu \mathrm{m}$ and then decreased sharply around minimum values of $3 \mu \mathrm{m}$. The otolith radius-TL relationship for the range of fish collected was linear:

$$
\mathrm{LT}=1.3607+0.0088 \times \text { otolith radius }
$$

where $P<0.01 ; n=250 ; R^{2}=0.80$.

This allowed back-calculation of previous length for each individual fish so as to obtain IGRs. Mean IGRs ranged from 

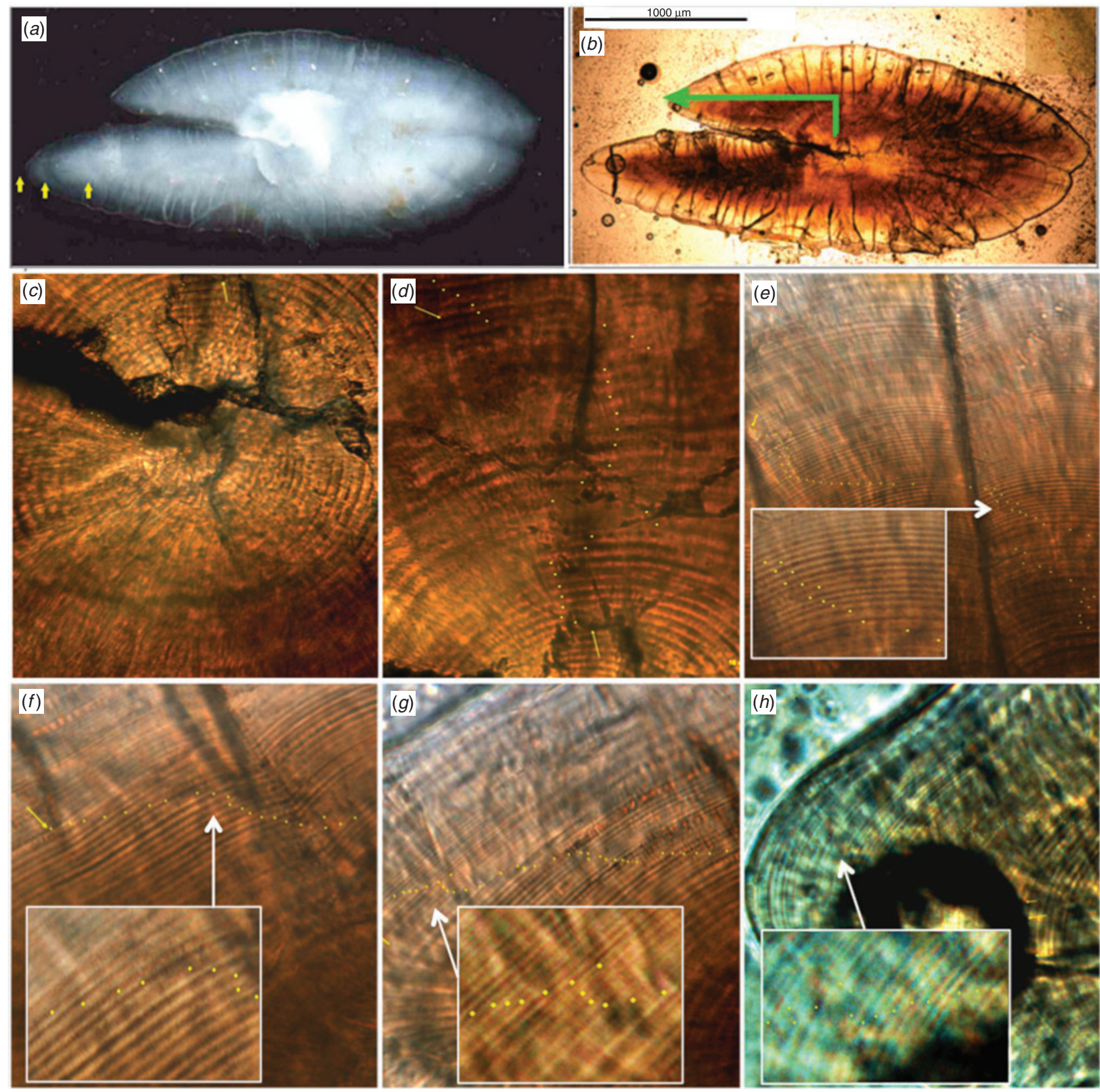

Fig. 3. Otolith macro- and microstructure from a 13.5 -cm total length and 204-day-old Engraulis ringens collected in northern Chile. (a) Image of the whole otolith taken under surface reading. The arrows indicate the macro hyaline rings of the half year according to current age assignment criteria. (b) Image of the same otolith once it was polished. The arrow indicates the reading axis. $(c-h)$ Sequence of primary micro-increments from the primordium to the antirostrum edge (original magnification $400 \times$ ). Insets show higher resolution images (original magnification $1000 \times$ ) of the areas shown.

0.27 to $1.68 \mathrm{~mm} \mathrm{day}^{-1}$, but with overall means $>0.7 \mathrm{~mm} \mathrm{day}^{-1}$ showing, in most cases, a decreasing tendency for the age range of collected fish, whereas IGRs $>1 \mathrm{~mm} \mathrm{day}^{-1}$ occurred even until approximately 75 days in juveniles (Fig. 7). In general, IGRs varied over age and monthly cohorts $(P<0.05$, repeatedmeasures ANOVA), with the winter cohorts showing higher overall mean growth rates (Table 3 ).

\section{Overall AGRs}

Overall AGRs ranged from 0.45 to $1.2 \mathrm{~mm} \mathrm{day}^{-1}$, showing high variability (Fig. 8). To establish whether there were significant differences in AGRs by hatch month, one-way ANOVA was performed excluding those months with a sample size $<13$ individuals. Mean log-transformed AGRs did not show significant differences $(P=0.23$, ANOVA $)$ between monthly cohorts. 


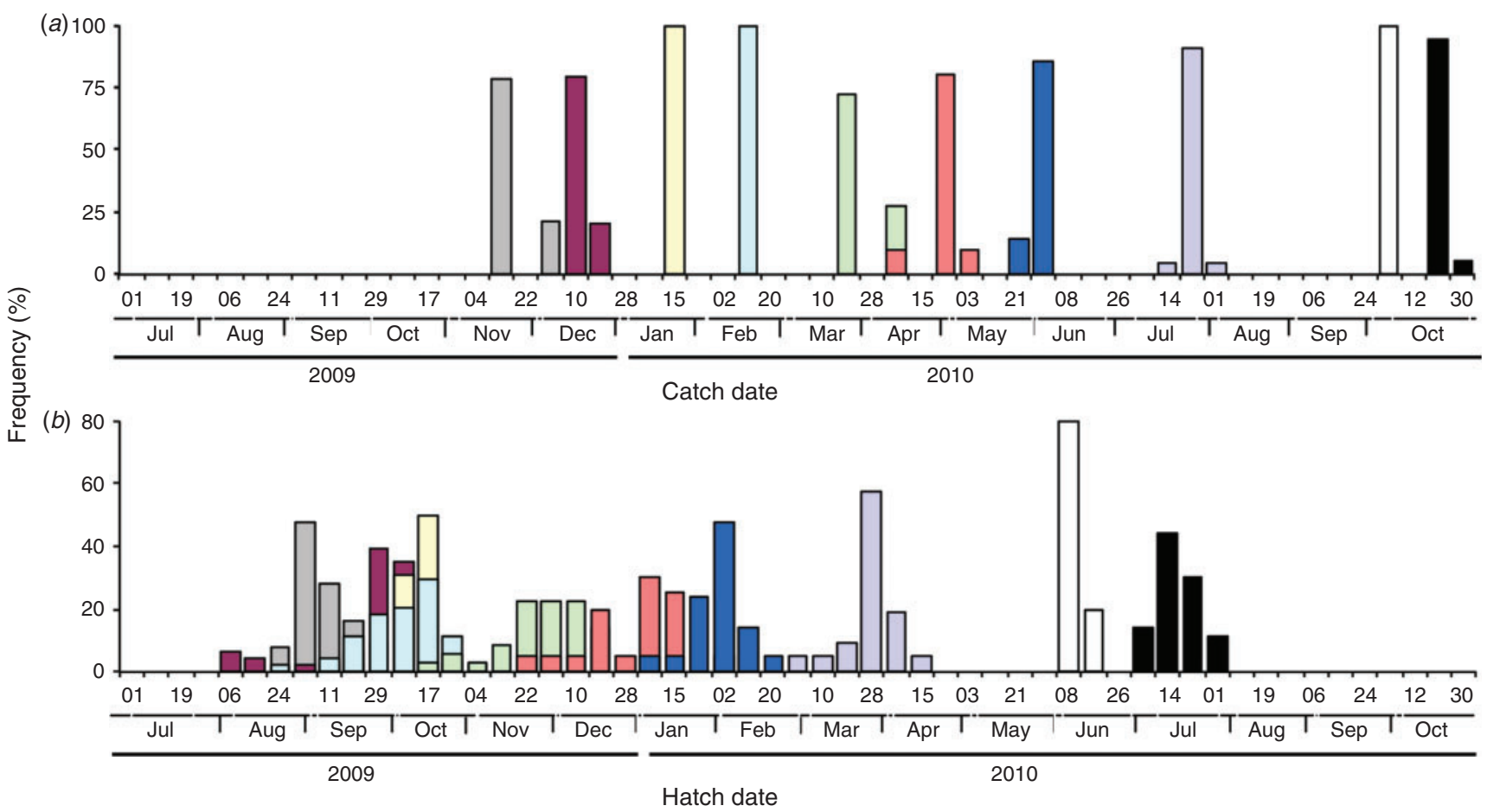

Fig. 4. Frequency distribution of (a) catch date and (b) hatch month of juvenile Engraulis ringens $\leq 12-\mathrm{cm}$ total length collected in northern Chile, illustrating the elapsed period from hatch to the time juveniles appears in hydroacoustic surveys.

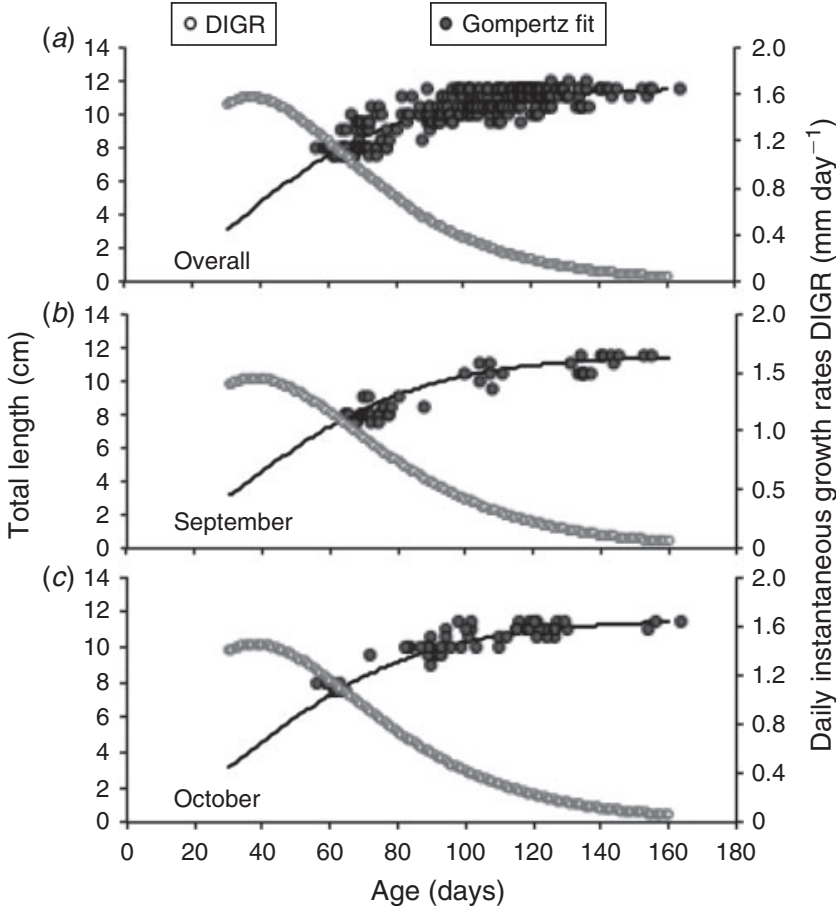

Fig. 5. Laird-Gompertz model fitted to the age-length relationship of juvenile Engraulis ringens, caught in northern of Chile from October 2009 to November 2010. Model parameters are given in Table 2. (a) Overall fish caught, $(b)$ fish caught in September, $(c)$ fish caught in October. DIGR, daily instantaneous growth rate.
Table 2. Parameters derived from Laird-Gompertz models fitted to the age-length relationship of juvenile Engraulis ringens between 7.5- and 12-cm total length, for monthly hatched and pooled cohorts $L_{\infty}$, asymptotic length; $X_{0}$, inflexion point of the curve; $\alpha$, instantaneous growth rate at age $X_{0}$; TL, total length; DIGR, daily instantaneous growth rate; $R^{2}$, determination coefficient

\begin{tabular}{lcccccc}
\hline Cohort & $L_{\infty}$ & $\alpha$ & $X_{0}$ & TL at $X_{0}$ & DIGR at $X_{0}$ & $R^{2}$ \\
\hline Global & 11.55 & 0.04 & 37.18 & 4.25 & 1.57 & 0.74 \\
September & 12.11 & 0.02 & 29.49 & 4.46 & 0.98 & 0.88 \\
October & 11.60 & 0.03 & 33.75 & 4.27 & 1.45 & 0.87 \\
\hline
\end{tabular}

\section{Integrated age-length relationship for juvenile} and adult fish

Overall, 458 fish were available for this analysis, of which 351 were juveniles $\leq 12 \mathrm{~cm} \mathrm{LT}$ and 107 were adult specimens whose age ranged from 137 to 409 days and TL ranged from 12.5 to $18 \mathrm{~cm}$ (Table 1). The log likelihood and AIC values show that the best fit to the age-length relationship corresponded to the seasonal von Bertalanffy model (Table 4). The model parameters show a somewhat high asymptotic length and greater $K$, reflecting the high rate growth. The $t_{0}$, the abscissa of the inflection point, is 74 days, $C$ indicates that $28 \%$ of the model appreciates a seasonal oscillation and $t_{s}$ indicates that the highest growth was recorded at 20 days. This model predicted a mean length of $16.3 \mathrm{~cm} \mathrm{TL}$ at the end of the first year of life for this species (Fig. 9). 
A comparison of micro- and macrostructure analyses for eight fish showed that most of the hyaline rings are formed before the first year of life. The daily micro-increment readings indicated that the first annulus should be formed around the time that the 5th or 6th hyaline ring is observed in annual readings of whole otoliths, corresponding to 2.5 or 3.0 years assigned using the current ageing criteria (Table 5).

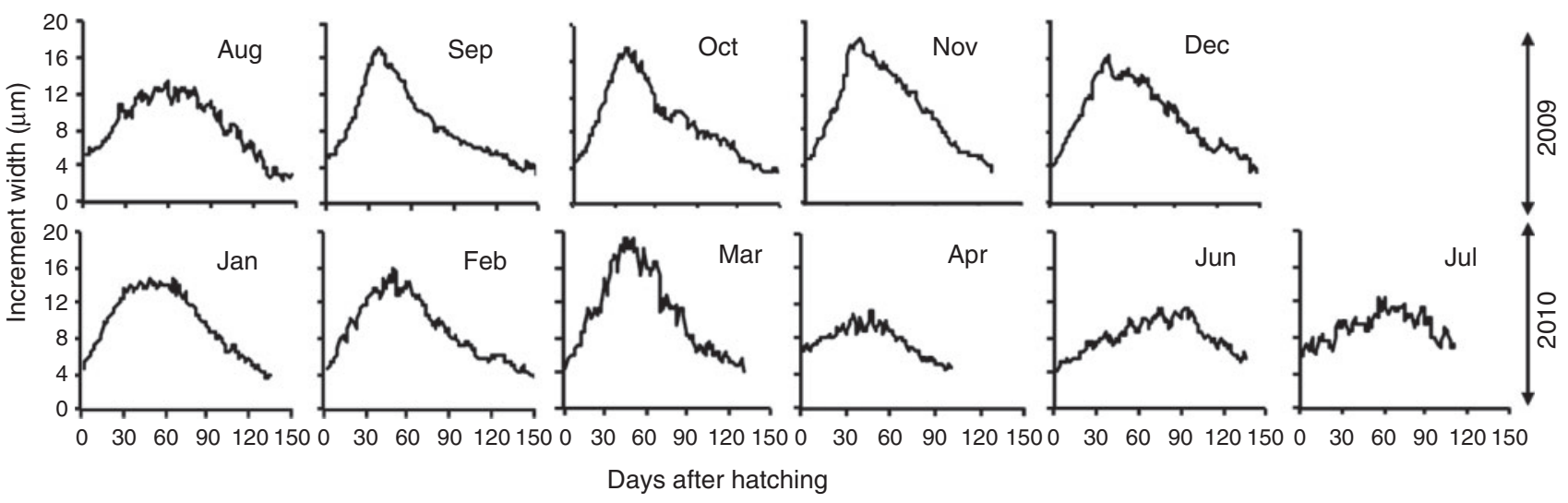

Fig. 6. Mean Increment width profiles by monthly hatched cohorts of juvenil Engraulis ringens, collected in northern of Chile from October 2009 to November 2010.

Table 3. General statistic of overall mean increment width and individual growth rates determined by monthly hatched cohorts of juveniles Engraulis ringens

HM, hatch month; s.d., standard deviation; $n$, sampling size

\begin{tabular}{|c|c|c|c|c|c|c|}
\hline \multirow[t]{2}{*}{ Year } & \multirow[t]{2}{*}{ HM } & \multicolumn{2}{|c|}{ Increment width $(\mu \mathrm{m})$} & \multicolumn{2}{|c|}{ Individual growth rates $\left(\mathrm{mm} \mathrm{day}^{-1}\right)$} & \multirow[t]{2}{*}{$n$} \\
\hline & & Mean \pm s.d. & Range & Mean \pm s.d. & Range & \\
\hline \multirow[t]{5}{*}{2009} & August & $9.19 \pm 2.73$ & $2.87-13.61$ & $0.92 \pm 0.27$ & $0.31-1.31$ & 12 \\
\hline & September & $8.72 \pm 3.94$ & $3.03-17.31$ & $0.67 \pm 0.40$ & $0.27-1.60$ & 105 \\
\hline & October & $9.12 \pm 4.08$ & $3.27-17.76$ & $0.65 \pm 0.39$ & $0.27-1.52$ & 24 \\
\hline & November & $10.31 \pm 4.32$ & $3.26-18.15$ & $0.73 \pm 0.36$ & $0.36-1.52$ & 22 \\
\hline & December & $9.31 \pm 3.62$ & $3.01-16.91$ & $0.75 \pm 0.35$ & $0.25-1.47$ & 16 \\
\hline \multirow[t]{6}{*}{2010} & January & $10.04 \pm 3.42$ & $4.17-16.24$ & $0.87 \pm 0.30$ & $0.36-1.31$ & 36 \\
\hline & February & $8.91 \pm 3.43$ & $3.61-16.22$ & $0.69 \pm 0.32$ & $0.30-1.34$ & 14 \\
\hline & March & $10.78 \pm 4.66$ & $4.13-20.58$ & $0.81 \pm 0.40$ & $0.33-1.68$ & 6 \\
\hline & April & $7.08 \pm 1.87$ & $4.00-11.75$ & $0.76 \pm 0.23$ & $0.39-1.13$ & 11 \\
\hline & June & $8.20 \pm 1.85$ & $3.80-12.27$ & $0.91 \pm 0.24$ & $0.38-1.22$ & 13 \\
\hline & July & $9.16 \pm 1.74$ & $5.50-13.78$ & $1.02 \pm 0.25$ & $0.56-1.39$ & 7 \\
\hline
\end{tabular}
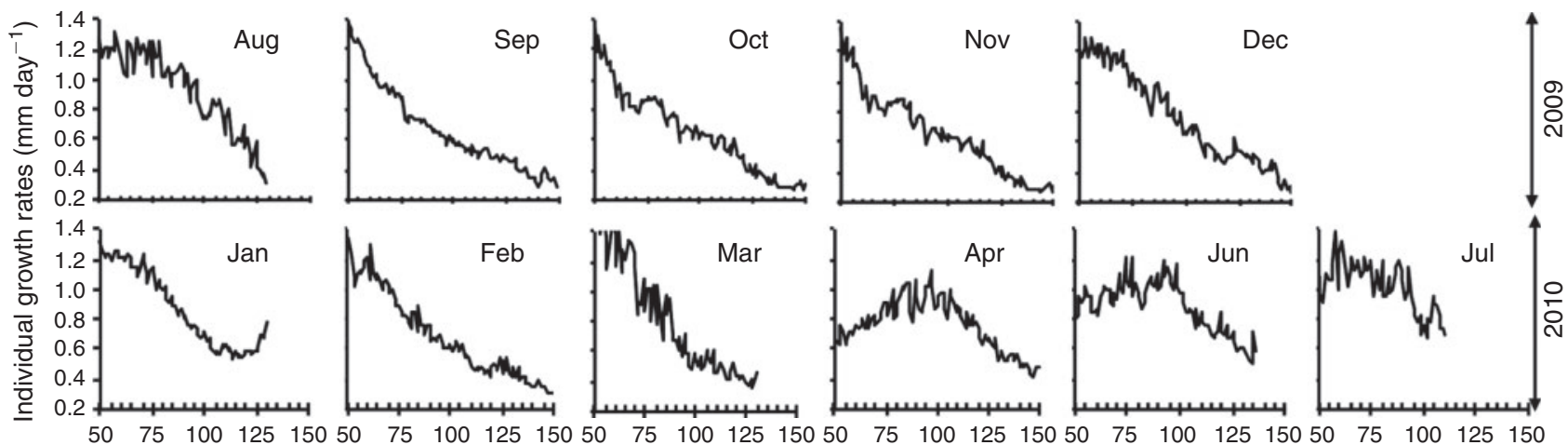

Jul

$\begin{array}{lllllllllll}50 & 75 & 100 & 125 & 150 & 50 & 75 & 100 & 125 & 150 & 50\end{array}$

Days after hatching

Fig. 7. Mean profiles of individual growth rates by monthly hatched cohorts of juvenile Engraulis ringens, collected in northern of Chile from October 2009 to November 2010 . 


\section{Discussion}

The four main findings of the present study are: (1) the existence of distinctive microstructural zones in sagittal otoliths in juveniles fish; (2) the existence of fast growth during the juvenile stage that triggers a quick recruitment to fisheries all year long; (3) the feasibility of ageing mature anchovy using primary increments of sagittal otoliths; and (4) the occurrence of inconsistencies in age determination derived from daily increments $v$. reading of annuli. Some aspects associated with these main results are discussed in detail below.

\section{Otolith microstructural features}

A distinctive feature was the occurrence of three microstructural zones in sagittal otoliths of immature fish: a first zone where primary increments were more homogeneous and easy to

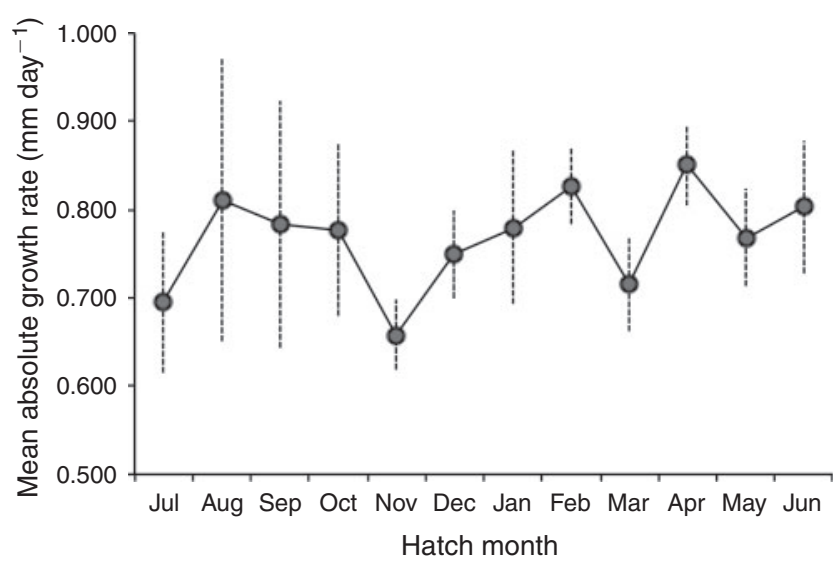

Fig. 8. Changes in mean absolute growth rate for each birth cohort throughout an annual cycle in juvenile Engraulis ringens collected in northern Chile. Data are the mean \pm s.d. identify, in contrast with a second zone where double rings and other perturbations predominated, and a third zone where increment width decreased, although good resolution was maintained. Microstructural zones in sagittal otoliths of youngof-the-year (YOY) have been reported in several teleost fish (Wellington and Victor 1989; Beldade et al. 2007; Sponaugle 2010; García-Seoane et al. 2015), particularly in demersal and reef-associated fish (Victor 1986; Wilson and McCormick 1997; Sponaugle 2010). These features have been linked roughly with the larval stage, the transition from larval to juvenile stages or habitat transitions, and later juvenile stages where juveniles occur in nursery areas or deeper habitats

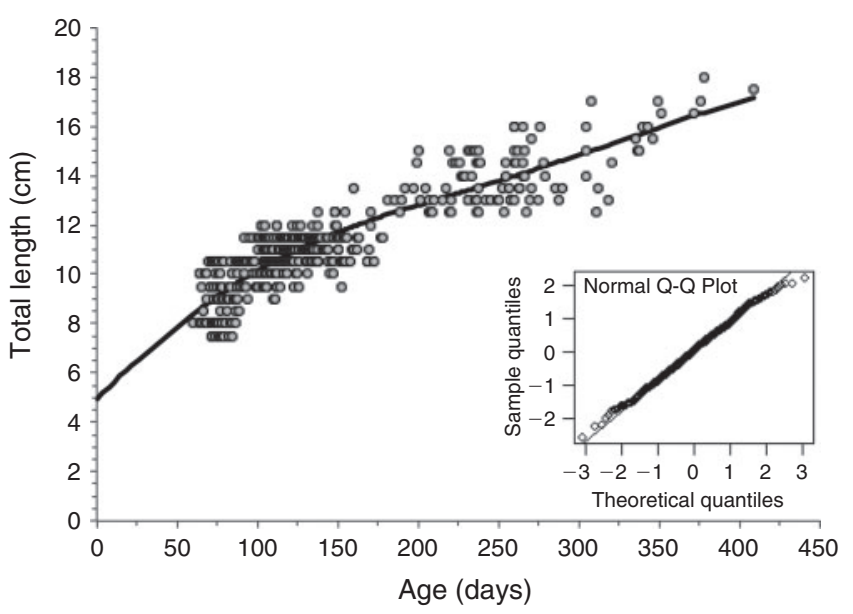

Fig. 9. Seasonal von Bertalanffy growth curve fitted to the age-length relationship of Engraulis ringens from waters off northern Chile. Inset, normal quantile-quantile plot (Q-Q plot) that is the plot of the values in ' $y$ ' around to the theoretical normal line ( $\mathrm{q}-\mathrm{q}$ line) that passes through the first and third quartiles.

Table 4. Growth parameters derived from von Bertalanffy conventional, Laird-Gompertz and von Bertalanffy seasonal models fitted to the agelength relationship of 458 anchovy (Engraulis ringens) between 7.5- and 18-cm total length, collected in northern Chile

s.e., standard error; logLike, negative log-likelihood; $R^{2}$, determination coefficient; AIC, Akaike information criterion; $W$, Shapiro-Wilk normality test; $L_{\infty}$, asymptotic length; $X_{0}$, inflexion point of the curve; $K$, growth coefficient; $t_{0}$, the age at which the fish has zero length; $\alpha$, instantaneous growth rate at age; $C$, dimensionless constant expressing the amplitude of a growth oscillation; $t_{s}$, time between Time 0 and the start of the convex portion of the first sinusoidal growth oscillation (i.e. the inflection point)

\begin{tabular}{|c|c|c|c|c|c|c|c|}
\hline & \multicolumn{2}{|c|}{ Parameters } & \multicolumn{3}{|c|}{ Statistical significance } & \multicolumn{2}{|c|}{ Normality test } \\
\hline & Mean & s.e. & -log likelihood & $R^{2}$ & AIC & $W$ & $P$-value \\
\hline \multicolumn{8}{|c|}{ von Bertalanffy } \\
\hline$L_{\infty}$ & 19.31 & 1.242 & $-587.9($ d.f. $=4)$ & 0.79 & 1183.9 & 0.9944 & 0.095 \\
\hline$K$ & 1.33 & 0.238 & & & & & \\
\hline$t_{0}$ & -0.28 & 0.049 & & & & & \\
\hline \multicolumn{8}{|c|}{ Laird-Gompertz } \\
\hline$L_{\infty}$ & 17.92 & 0.784 & $-589.8($ d.f. $=4)$ & 0.79 & 1187.7 & 0.9940 & 0.070 \\
\hline$\alpha$ & 2.05 & 0.249 & & & & & \\
\hline$X_{0}$ & 12.34 & 0.012 & & & & & \\
\hline \multicolumn{8}{|c|}{ Seasonal von Bertalanffy } \\
\hline$L_{\infty}$ & 22.00 & 5.709 & $-583.0($ d.f. $=5)$ & 0.79 & 1178.1 & 0.9969 & 0.527 \\
\hline$K$ & 1.09 & 0.707 & & & & & \\
\hline$t_{0}$ & -0.21 & 0.178 & & & & & \\
\hline$C$ & 0.28 & 0.078 & & & & & \\
\hline$t_{s}$ & 21.90 & 0.101 & & & & & \\
\hline
\end{tabular}


Table 5. Comparative analysis between macrostructure and microstructura in eight sagittal otoliths of juveniles and adults Engraulis ringens collected in northern Chile. In the current ageing criteria two hyaline rings counted under surface reading of whole sagittal otoliths encompass one annulus

For the present ageing criteria, two hyaline rings counted under surface reading of entire sagittal otoliths encompass one annulus

\begin{tabular}{|c|c|c|c|c|c|}
\hline \multirow[t]{2}{*}{ Total length $(\mathrm{cm})$} & \multicolumn{3}{|c|}{ Otolith macrostructure } & \multicolumn{2}{|c|}{ Otolith microstructure } \\
\hline & Age (years) & Number of hyaline rings & Diameter of hyaline rings $(\mathrm{mm})$ & Age (days) & Age (month) \\
\hline 10.5 & 0.5 & 1 & 2.34 & 110 & 3.7 \\
\hline 12.3 & 1.0 & 2 & 2.93 & 177 & 5.9 \\
\hline 13.9 & 1.5 & 3 & 3.38 & 257 & 8.6 \\
\hline 12.2 & 2.0 & 4 & 3.75 & 318 & 10.6 \\
\hline 15.8 & 2.5 & 5 & 4.02 & 346 & 11.5 \\
\hline 16.5 & 3.0 & 6 & 4.23 & 376 & 12.5 \\
\hline 17.1 & 3.5 & 7 & 4.38 & 409 & 13.6 \\
\hline 17.5 & 4.0 & 8 & 4.55 & 429 & 14.3 \\
\hline
\end{tabular}

(Jenkins and May 1994; Raventós and Macpherson 2001; Plaza et al. 2001; Mansur et al. 2014). Conversely, abrupt changes in otolith microstructure seem to be less common in sagittal otoliths of YOY of pelagic fish where habitat transition is less marked. However, subdaily rings, double and triple microincrements, discontinuities and other perturbations have been reported in some areas of sagittal otoliths in recent studies in other pelagic fish and in some engraulids (Palomera et al. 1988; Cermeño et al. 2006; Cermeño et al. 2008; Namiki et al. 2010), similar to the microstructural features observed in the transition zone in E. ringens in the present study.

The existence of double and triple micro-increments in the otoliths of juveniles has been well characterised in E. encrasicolus of the Bay of Biscay by Cermeño et al. (2008). These authors compared two criteria for reading otolith microincrements in this species, namely individual mark reading (IMR), where each micro-increment, regardless of its appearance, was considered as a daily count, $v$. group band reading (GBR), where a repetitive cyclic set of growth bands was taken as a single daily increment. Cermeño et al. (2008) concluded that GBR was the most reliable ageing procedure for E. encracicolus. Conversely, Plaza and Cerna (2015) reported a closer correspondence between daily age and number of increments when double rings were counted separately in juvenile $E$. ringens produced under rearing conditions, although double rings were restricted only to the transition zone (i.e. Zone B) and consequently age underestimation was marginal.

However, under rearing conditions, the identification of micro-structural zones in E. ringens was very distinctive (Plaza and Cerna 2015) compared with otolith microstructure of wild juveniles where boundaries between zones are not easily identified. Hence, the use of GBR is far more consistent for the identification of primary micro-increments in wild specimens. Nevertheless, because it is not feasible to use validation procedures to mark otoliths every day, the periodicity of the formation of double and triple structures in engraulids and other pelagic fish will remain unaddressed. However, an indirect validation has been reported using an index of completion of the marginal increment for juveniles of the skipjack Katsuwonus pelamis, a very fast-growing tropical tuna $\left(\sim 3 \mathrm{~mm} \mathrm{day}^{-1}\right.$; Tanabe et al. 2003). In that study, up to 10 distinctive subdaily increments were observed between daily increments. From this finding and the results of the present study, it is reasonable to infer that the occurrence of double and triple structures is further evidence of fast growth during the juvenile phase of $E$. ringens.

\section{Fast growth before recruitment}

Daily instantaneous growth rates (DIGR) at the inflection point derived from immature E. ringens ranged from 0.98 and $1.57 \mathrm{~mm} \mathrm{day}^{-1}$ reached at approximately Days 29 and 37 of life for fish between 7.5 and $12 \mathrm{~cm}$ TL respectively. To date, most studies using a similar methodology have been restricted to earlier stages of development in other engraulids; however, this information can be useful to discuss the results of the present study. For E. mordax, the reported instantaneous growth rates have raged from 0.36 to $0.55 \mathrm{~mm}^{-1 a y}{ }^{-1}$ for juveniles between 10 and $35 \mathrm{~mm}$ long (Hunter 1976; Methot 1983; Butler 1989). Similarly, growth rates ranged between 0.49 and $0.73 \mathrm{~mm}$ day $^{-1}$ for E. japonicus for lengths of 5-35 mm (Mitani 1990; Takahashi et al. 2001; Takahashi and Watanabe 2004). Recently Cermeño et al. (2008) reported growth rates between 0.56 and $0.77 \mathrm{~mm} \mathrm{day}^{-1}$ for juvenile E. encrasicolus between 5 and $53 \mathrm{~mm}$ standard length (SL) and 5 and 90 days of age in the Cantabrian Sea, whereas La Mesa et al. (2009) reported a growth rate of $0.68 \mathrm{~mm} \mathrm{day}^{-1}$ for juveniles of the same species between 10 and $60 \mathrm{~mm}$ TL in the Adriatic Sea. Based on these studies and the high values of both DIGRs and overall AGRs (0.8-1.2 mm day $^{-1}$ ) for $E$. ringens, it seems growth resumes again after metamorphosis, maintaining an allometric growth pattern as well.

The high growth rates derived from fitting age-length model at capture were confirmed when back-calculation procedures were applied to the age range of fish collected. This approach showed that in all monthly cohorts mean overall IGR was higher than $0.7 \mathrm{~mm} \mathrm{day}^{-1}$ and close to $1 \mathrm{~mm}^{\text {day }}{ }^{-1}$ in winter months, although, regardless of cohort, a gradual decrease in IGRs occurred after the second month of life. This consistent pattern was also observed when analysing seasonal changes in increment width profiles, where most otolith growth rate variation occurred during the first 60 days of juvenile life, regardless of cohort, with a domed-shaped $v$. pyramidal-shaped pattern for spring-summer $v$. autumn-winter cohorts respectively. 
Certainly, the upward trend in the first stage suggests a period of accelerated growth, because larvae are able to feed independently. Importantly, during this period there is continuous development of morphological and sensory aspects of larvae, which increases their motility and ability to capture prey (O'Connell 1981; Thorrold and Williams 1989). Therefore, an ontogenetic growth increase could be expected, although the changes in magnitude could be modulated by growth controllers as the season progresses for E. ringens, where the growth increase is less marked in winter cohorts that have been affected by lower water temperature, but with a compensatory effect at older ages. However, differences in otolith growth patterns between autumn-winter and spring-summer cohorts are not so marked, which is indicative of favourable conditions for early growth for these species all year round. Indeed, some studies on the feeding of larval fish have demonstrated that although larval food abundance may vary among seasons and localities along the HCS in Chile, starvation due to limited food availability alone does not seem to be such a common feature in this species, even in seasons of lower production (autumn and winter; Pizarro et al. 1998; Castro et al. 2000, Hernández and Castro 2000; Thiel et al. 2007). Moreover, for E. ringens in northern Chile, a low incidence of starvation was reported during autumn (Pizarro et al. 1998). Furthermore, upwelling favourable winds are rather constant throughout the year from $26^{\circ} \mathrm{S}$ northwards (Figueroa 2002; Thiel et al. 2007), which triggers high productivity in this area of the HCS, one of the most productive marine ecosystems on Earth (Thiel et al. 2007). The confluence of favourable environmental conditions that trigger fast growth during the early vulnerable stages seems to be very advantageous, and has seen the development of a batch-spawning strategy to produce huge numbers of small eggs over a very protracted spawning season, such as reported previously for this species (Plaza et al. 2002; Claramunt et al. 2012).

A further feature when analysing seasonal changes in increment width profiles by monthly cohorts was that most of the variability in otolith growth in recruits (true survivors) was concentrated in the first 2 months of juvenile life, a period that would have very important consequences for the survival of this species. In this sense, it is important to note that several studies have indicated that growth in the early stages seems to be linked to increased larval and juvenile survival (Anderson 1988; Hare and Cowen 1997; Sirois and Dodson 2000; Takasuka et al. 2004; Shoji and Tanaka 2006) and thus be a precursor of year-class strength (Campana 1996; Robert et al. 2007; Takahashi et al. 2012). Hence, cumulative otolith growth during this period back-calculated from survivors could be used as explanatory variable when searching for proxies to anticipate the stock condition of E. ringens. Such an approach applied to a longer time series can be achieved because otoliths of immature $E$. ringens remain stored as part of its stock assessment process.

The marked decrease in growth during the later juvenile stage was also evidenced in the instantaneous growth rates for the age and length ranges of analysed fish. Considering the minimal DIGR estimated by the model (e.g. $0.06 \mathrm{~mm} \mathrm{day}^{-1}$ ), it would take $\sim 70$ remaining days to reach $12 \mathrm{~cm}$ TL. These projections are consistent with the upper age ranges found (120 140 days) for juveniles between 11.5 and $12.5 \mathrm{~cm}$ TL. The decrease in growth in the late juvenile stages matched the formation of a faint hyaline zone occurring in some juveniles at approximately Day 80 of life, which could explain the decrease in growth rate. However, micro-increments within this zone were also very distinctive, maintaining their characteristic appearance and resolution without interruption, in contrast with reports in some species of teleost fish in which microincrements were used to validate the first annuli (Brothers et al. 1976; Campana 2001; Wright et al. 2002; Cermeño et al. 2003; La Mesa 2007; Paul and Horn 2009; Hüssy et al. 2010). In most of these studies, complete sequences of microincrements were not visible; rather, extrapolation procedures were used in certain areas for validation. Furthermore, in the present study distinctive micro-increments were visible at $400 \times$ and $1000 \times$ magnification up the otolith edge in mature fish $>12 \mathrm{~cm}$ TL, suggesting that the characteristic rapid growth found in the early stages seems to extend to later stages of the life cycle of this species, where the macroscopically visible hyaline rings in whole otoliths tend to disappear from the macrostructure once the otolith is polished. In addition, at the edge of the otolith from adult fish, micro-increments were well defined, with an average increment width of $1.03 \mu \mathrm{m}$ (range $0.78-1.3 \mu \mathrm{m}$ ) measured at $1000 \times$ magnification, which is above the theoretical limit of light microscopy resolution of $0.2 \mu \mathrm{m}$ (Campana and Neilson 1985). Similar values of increment width have recently been reported for E. japonicus by Namiki et al. (2010), with mean values ranging from 1.8 to $3.1 \mu \mathrm{m}$ in mature anchovies. Conversely, in studies where true annuli have been validated, the hyaline and opaque rings contained thinner and wider increment widths respectively, even in the former absence of primary micro-increments because of the fusion process, which is characteristic of either a sharp decrease of somatic growth or ceasing of growth entirely (Waldron and Kerstan 2001; Wright et al. 2002). Such a microstructural feature of true annulus was not observed in sagittal otoliths of mature E. ringens.

The occurrence of a complete sequence of daily microincrements from the primordium to the otolith edge in both immature and mature fish of $E$. ringens allowed integration of a larger fraction of the life history of this species, where the seasonal von Bertalanffy model was well fitted to the data. However, this model estimated a larger asymptotic length $(22 \mathrm{~cm} \mathrm{TL})$ than that reported in other studies for this species using age-based traditional von Bertalanffy models and modal progression analysis (Cubillos et al. 2001). It could be argued that this estimate is an overestimation because of a lack of data for fish $<7 \mathrm{~cm} \mathrm{LT}$, where the curve cannot adequately follow the trend of the data preceding this size. In addition, the ' $C$ ' parameters should be much more representative of seasonal growth if data for fish $<6 \mathrm{~cm}$ TL could be incorporated in the analysis. Conversely, the three models estimated higher $K$ coefficients than previous studies (Cubillos et al. 2001), which seems indicative of enhanced growth through the late juvenile and adult stage of this species.

\section{Implications for fishery management}

Enhanced growth during the late juvenile and adult stages of $E$. ringens agrees with recent studies in other clupeoids, which have also reported fast growth. In a recent study performed by Namiki et al. (2010), it was possible to age adult fish of the 
Japanese anchovy (E. japonicus) by counting daily increments in specimens ranging from 8 to $14 \mathrm{~cm} \mathrm{SL}$. All aged specimens were $<365$ days (i.e. 1 year), with the largest fish being 329 days of age. Further evidence of fast growth come from two recent studies using otolith microstructure analysis in E. encrasicolus in the Gulf of Biscay (Aldanondo et al. 2011) and in the Adriatic Sea (La Mesa et al. 2009; Durovic et al. 2012). These studies demonstrated that juveniles can attain $6-8 \mathrm{~cm}$ in $\sim 70-90$ days. In the study of Aldanondo et al. (2011) in the Gulf of Biscay, the age of the larger fish $(\sim 14 \mathrm{~cm} \mathrm{SL})$ was less than 1 year of life. Based on this evidence and the results of high growth for E. ringens, some questions arise, specifically, to what extent is the Peruvian anchovy a species that maximizes its growth during the first year of life before markedly reducing growth to perhaps maximise reproduction? Alternatively, are the fast growth patterns observed in juveniles and adults in the present study restricted to a particular year, geographical area or hatch month, perhaps linked to the enhanced environmental conditions of growth controllers? Under a fast growth scenario, a considerable proportion of the asymptotic length will probably be reached in only a few months of life, where year-class strength will be the result of survival rates occurring just one season before; this could have a considerable effect on the management of anchovy fisheries. Hence, it is worth attempting to address these questions given the commercial and ecological importance of E. ringens in the HCS. A comprehensive study using similar methods to those described herein but on wider spatial and temporal scales throughout the distribution range of this species would be one way to address these issues.

The daily age determinations of adult E. ringens derived from otolith microstructure analysis are not consistent with the current reading criteria of annual growth rings because overestimation of age was evident. Such a finding could have important implications for stock assessment of this species because the annual age structure will overestimate the high frequency of variability within a year, which is caused by monthly recruitment variation as a result of the high growth during the juvenile phase of this species. In this new scenario, some consideration are crucial: (1) over $90 \%$ of the catch of a year would be recruiting; (2) the high growth would lead to increased natural mortality; and (3) it could be necessary to change biological reference points or include other types of management indicators. Although the effect can be dramatic from the perspective of stock assessment using complex agestructured models, from an alternative view the feasibility of reaching asymptotic length at a very early age could be an opportunity to make the stock assessment and management of anchovies, or small pelagic fish in general, work on simple rules supported by their own biology. As Hilborn (2003) said: 'I believe we should and will move towards using management procedures in which regulations are modified using rules that directly use data or very simple models.'

\section{Acknowledgments}

This study was founded by grants FIP 2009-16, SUBPESCA number 472831-LP11 and FONDECYT 1170740, awarded to G. Plaza and F. Cerna. The authors thank G. Moyano, J. Legua and M. Gómez for preparing and reading the otolith micro-increments.

\section{References}

Aguayo, M. (1976). Edad y Crecimiento de la anchoveta (Engraulis ringens, Jenyns) del norte de Chile (Arica-Iquique). Instituto de Fomento Pesquero, Santiago de Chile, Chile.

Akaike, H. (1974). A new look at the statistical model identification. IEEE Transactions on Automatic Control 19, 716-723. doi:10.1109/TAC. 1974.1100705

Aldanondo, N., Cotano, U., and Etxebeste, E. (2011). Growth of young-ofthe-year European anchovy (Engraulis encrasicolus, L.) in the Bay of Biscay. Scientia Marina 75, 227-235.

Anderson, J. (1988). A review of size dependent survival during pre-recruit stages of fishes in relation to recruitment. Journal of Northwest Atlantic Fishery Science 8, 55-66.

Aranda, M. (2009). Developments on fisheries management in Peru: the new individual vessel quota system for the anchoveta fishery. Fisheries Research 96, 308-312. doi:10.1016/J.FISHRES.2008.11.004

Bakun, A., and Weeks, S. J. (2008). The marine ecosystem off Peru: what are the secrets of its fishery productivity and what might its future hold? Progress in Oceanography 79, 290-299. doi:10.1016/J.POCEAN.2008. 10.027

Beamish, R. J., and McFarlane, G. A. (1987). Current trends in age determination methodology. In 'Age and Growth of Fish'. (Eds R. C. Summerfelt and G. E. Hall.) pp. 15-42. (Iowa State University Press: Ames, IA.)

Beldade, R., Pedro, T., and Goncalves, J. (2007). Pelagic larval duration of 10 temperate cryptobenthic fishes. Journal of Fish Biology 71, 376-382. doi:10.1111/J.1095-8649.2007.01491.X

Brothers, E. B., Mathews, C. P., and Lasker, R. (1976). Daily growth increments in otoliths from larval and adults fishes. Fishery Bulletin 74, 1-8.

Butler, J. L. (1989). Growth during the larval and juvenile stages of the northern anchovy, Engraulis mordax, in the California Current during 1980-84. Fishery Bulletin 87, 645-652.

Campana, S. E. (1990). How reliable are growth back-calculations based on otoliths? Canadian Journal of Fisheries and Aquatic Sciences 47, 22192227. doi:10.1139/F90-246

Campana, S. E. (1992). Measurement and interpretation of the microstructure of fish otoliths. In 'Otolith Microstructure Examination and Analysis. Canadian Special Publication of Fisheries and Aquatic Science. Vol. 117'. (Eds D. K. Stevenson and S. E. Campana.) pp. 59-71. (Canadian Department of Fisheries and Oceans: Ottawa, ON.)

Campana, S. E. (1996). Year-class strength and growth rate in young Atlantic cod Gadus morhua. Marine Ecology Progress Series 135, 21-26. doi:10.3354/MEPS135021

Campana, S. E. (2001). Accuracy, precision and quality control in age determination, including a review of the use and abuse of age validation methods. Journal of Fish Biology 59, 197-242. doi:10.1111/J.10958649.2001.TB00127.X

Campana, E. S., and Jones, C. M. (1992). Analysis of otolith microstructure data. In 'Otolith Microstructure Examination and Analysis. Canadian Special Publication of Fisheries and Aquatic Science. Vol. 117'. (Eds D. K. Stevenson and S. E. Campana.) pp. 73-100. (Canadian Department of Fisheries and Oceans: Ottawa, ON.)

Campana, S. E., and Neilson, J. D. (1985). Microstructure of fish otoliths. Canadian Journal of Fisheries and Aquatic Sciences 42, 1014-1032. doi:10.1139/F85-127

Canales, M., and Leal, E. (2009). Parámetros de historia de vida de la anchoveta Engraulis ringens Jenyns, 1842, en la zona centro norte de Chile. Revista de Biología Marina y Oceanografía 44, 173-179.

Casselman, J. M. (1990). Growth and relative size of calcified structures of fish. Transactions of the American Fisheries Society 119, 673-688. doi:10.1577/1548-8659(1990)119<0673:GARSOC > 2.3.CO;2

Castro, L. R., and Hernández, E. H. (2000). Early life survival of the anchoveta Engraulis ringens off Central Chile during the 1995 and 
1996 winter spawning seasons. Transactions of the American Fisheries Society 129, 1107-1117. doi:10.1577/1548-8659(2000)129<1107: ELSOTA $>2.0 . \mathrm{CO} ; 2$

Castro, L. R., Salinas, G. R., and Hernández, E. H. (2000). Environmental influences on winter spawning of the anchoveta Engraulis ringens off central Chile. Marine Ecology Progress Series 197, 247-258. doi:10.3354/MEPS197247

Cermeño, P., Uriarte, A., Murgia, D. A. M., and Morales-Nin, B. (2003). Validation of daily increment formation in otoliths of juvenile and adult European anchovy. Journal of Fish Biology 62, 679-691. doi:10.1046/ J.1095-8649.2003.00056.X

Cermeño, P., Morales-Nin, B., and Uriarte, A. (2006). Juvenile European anchovy otolith microstructure. Scientia Marina 70, 553-557. doi:10.3989/SCIMAR.2006.70N3553

Cermeño, P., Uriarte, A., Morales-nin, B., Cotano, M., and Alvarez, P. (2008). Setting up interpretation criteria for ageing juvenile European anchovy otoliths. Scientia Marina 72, 733-742.

Chambers, R. C., and Miller, T. J. (1995). Statistical analysis of reconstructed life histories from otoliths: special properties of longitudinal data. In 'Recent Developments in Fish Otolith Research'. (Eds D. Secor, J. Dean and S. E. Campana.) pp. 155-175. (University of South Carolina Press: Columbia, SC.)

Chirinos, A., and Chumán, E. (1968). Validez de la lectura de otolitos para determinar la edad de la anchoveta (Engraulis ringens). Informe Técnico. Instituto del Mar del Perú (IMARPE), Callao, Perú, 22, 1-34. Available at http://biblioimarpe.imarpe.gob.pe:8080/bitstream/handle/ 123456789/250/INF\%2022.pdf?sequence $=1$ [Verified 28 February $2016]$.

Claramunt, G., Castro, L. R., Cubillos, L. A., Hirche, H.-J., Perez, G., and Braun, M. (2012). Inter-annual reproductive trait variation and spawning habitat preferences of Engraulis ringens off northern Chile. Revista de Biología Marina y Oceanografía 47, 227-243. doi:10.4067/S071819572012000200006

Cubillos, L. A., Arcos, D. F., Bucarey, D. A., and Canales, M. T. (2001). Seasonal growth of small pelagic fish off Talcahuano, Chile $\left(37^{\circ} \mathrm{S}\right.$, $73^{\circ} \mathrm{W}$ ): a consequence of their reproductive strategy to seasonal upwelling? Aquatic Living Resources 14, 115-124. doi:10.1016/S0990-7440 (01)01112-3

Durovic, M., Pesic, A., Regner, S., Joksimovic, A., Mandic, M., Kasalica, O., Ikica, Z., and Krpo-Ċetkovic, J. (2012). Daily otolith increments and growth rate of juvenile anchovy, Engraulis encrasicolus (Linnaeus, 1758), in the south-eastern Adriatic Sea. Acta Adriatica 53, 331-340.

Espinoza, P., and Bertrand, A. (2008). Revisiting Peruvian anchovy (Engraulis ringens) trophodynamics provides a new vision of the Humboldt Current system. Progress in Oceanography 79, 215-227. doi:10.1016/J.POCEAN.2008.10.022

Figueroa, D. (2002). Forcing of physical exchanges in the nearshore Chilean ocean. In 'The Oceanography and Ecology of the Nearshore and Bays in Chile'. (Eds J. C. Castilla and J. L. Largier.) pp. 31-43. (Universidad Católica de Chile: Santiago, Chile.)

Gallardo-Cabello, M. (1985). Determinación de la edad de la anchoveta Engraulis mordaz Girard, en aguas de Baja California Norte (Pisces: Engraulidae). Anales Instituto Ciencias del Mar y Limnología 12, 221-234.

García-Berthou, E., Carmona-Catot, G., Merciai, R., and Ogle, D. H. (2012). A technical note on seasonal growth models. Reviews in Fish Biology and Fisheries 22, 635-640. doi:10.1007/S11160-012-9262-X

García-Seoane, E., Meneses, A. C. I., and Silva, B. (2015). Microstructure of the otoliths of the glacier lanternfish, Benthosema glaciale. Marine and Freshwater Research 66, 70-77. doi:10.1071/MF13211

Geffen, A. J. (1982). Otolith ring deposition in relation to growth rate in herring (Clupea harengus) and turbot (Scophthalmus maximus) larvae. Marine Biology 71, 317-326. doi:10.1007/BF00397048
Hare, J. A., and Cowen, K. C. (1997). Size, growth, development and survival of the planktonic larvae of Pomatomus saltatrix (Pisces: Pomatomidae). Ecology 78, 2415-2431. doi:10.2307/2265903

Hernández, E. H., and Castro, L. R. (2000). Larval growth of the anchoveta Engraulis ringens during the inter-spawning season off central Chile. Fishery Bulletin 98, 704-710.

Hilborn, R. (2003). The state of the art in stock assessment: where we are and where we are going. Scientia Marina 67, 15-20.

Hunter, J. R. (1976). Culture and growth of Northern Anchovy Engraulis mordax, larvae. Fishery Bulletin 74, 81-88.

Hüssy, K., Hinrichsen, H., Fey, D. P., Walther, Y., and Velasco, A. (2010). The use of otolith microstructure to estimate age in adult Atlantic cod Gadus morhua. Journal of Fish Biology 76, 1640-1654. doi:10.1111/ J.1095-8649.2010.02602.X

Ihaka, R., and Gentleman, R. (1996). R: a language for data analysis and graphics. Journal of Computational and Graphical Statistics $\mathbf{5}$ 299-314

Jenkins, G. P., and May, H. M. A. (1994). Variation in settlement and larval duration of King George whiting, Sillaginodes punctata (Sillaginidae), in Swan Bay, Victoria, Australia. Bulletin of Marine Science 54, 281-296.

La Mesa, M. (2007). The utility of otolith microstructure in determining the timing and position of the first annulus in juvenile Antarctic toothfish (Dissostichus mawsoni) from the South Shetland Islands. Polar Biology 30, 1219-1226. doi:10.1007/S00300-007-0281-3

La Mesa, M., Donato, F., Giannetti, G., and Arneri, E. (2009). Growth and mortality rates of European anchovy (Engraulis encrasicolus) in the Adriatic Sea during the transition from larval to juvenile stages. Fisheries Research 96, 275-280. doi:10.1016/J.FISHRES.2008.12.011

Llanos-Rivera, A., and Castro, L. (2006). Interpopulation differences in temperature effects on Engraulis ringens yolk-sac larvae. Marine Ecology Progress Series 312, 245-253. doi:10.3354/MEPS312245

Ludynia, K., Garthe, S., and Luna-Jorquera, G. (2010). Distribution and foraging behaviour of the Peruvian booby (Sula variegata) off northern Chile. Journal für Ornithologie 151, 103-111. doi:10.1007/S10336009-0431-1

Mansur, L., Plaza, G., Landaeta, M. F., and Ojeda, F. P. (2014). Planktonic duration in fourteen species of intertidal rocky fishes from the southeastern Pacific Ocean. Marine and Freshwater Research 65, 901-909. doi:10.1071/MF13064

Methot, R. D. (1983). Seasonal variation in survival of larval northern anchovy, Engraulis mordax, estimated from the age distribution of juveniles. Fishery Bulletin 81, 741-750.

Mitani, I. (1990). The biological studies on the larvae of Japanese anchovy, Engraulis japonica Houttuyn, in Sagami Bay. Special Report 5, Kanagawa Prefectural Fishery Experimental Station.

Morales-Nin, B. (1989). Age and growth of the southern stock of Peruvian anchoveta based otolith microstructures and length frequency analysis In 'Proceedings 18 ICLARM Conference', 24-28 August 1987, Callao, Peru. (Eds D. Pauly, J. Mendo and I. Tsukayama.) pp. 179-188. (Instituto del Mar del Perú (IMARPE): Callao, Perú.)

Namiki, S., Tanaka, H., Katayama, S., Funaki, O., Aoki, I., and Oozeki, Y. (2010). Validation of daily increment formation in otolith of immature and adult Japanese anchovy Engraulis japonicus. Fisheries Science 76, 951-959. doi:10.1007/S12562-010-0292-9

O'Connell, C. P. (1981). Development of organ systems in the northern anchovy Engraulismordax and other teleosts. American Zoologist 21, 429-446. doi:10.1093/ICB/21.2.429

Palomera, I., Morales, B., and Lleonart, J. (1988). Larval growth of anchovy, Engraulis encrasicolus, in the western Mediterranean Sea. Marine Biology 99, 283-291. doi:10.1007/BF00391991

Panfili, J., de Pontual, H., Troadec, H., and Wright, P. (Eds) (2002). 'Manual of Fish Sclerochronology.' (Ifremer-IRD: Brest.) Available at http:/ archimer.ifremer.fr/doc/00017/12801/9742.pdf [Verified 8 April 2016] 
Pannella, G. (1971). Fish otoliths: daily growth layers and periodical patterns. Science 173, 1124-1127. doi:10.1126/SCIENCE.173. 4002.1124

Paul, L. J., and Horn, P. L. (2009). Age and growth of sea perch (Helicolenus percoides) from two adjacent areas off the east coast of South Island, New Zealand. Fisheries Research 95, 169-180. doi:10.1016/J.FISH RES.2008.08.011

Pauly, D., and Tsukayama, I. (1987). The Peruvian anchoveta and its upwelling ecosystem: three decades of change. ICLARM Studies and Reviews 15, 1-13.

Pizarro, E., Palma, W., and Flores, C. (1998). Validación de la hipótesis de mortalidad por inanición en larvas de Engraulis ringens Jenyns, 1842 (Pisces: Engraulidae), utilizando el criterio histológico en un área de surgencia costera en el norte de Chile. Investigaciones Marinas 26, 97-108. doi:10.4067/S0717-71781998002600009

Plaza, G., and Cerna, F. (2015). Validation of daily microincrement deposition in otoliths of juvenile and adult Peruvian anchovy Engraulis ringens. Journal of Fish Biology 86, 203-216. doi:10.1111/JFB.12561

Plaza, G., Katayama, S., and Omori, M. (2001). Otolith microstructure of the black rockfish, Sebastes inermis. Marine Biology 139, 797-805. doi: $10.1007 /$ S002270100620

Plaza, G., Claramunt, G., and Herrera, G. (2002). An intra-annual analysis of intermediate fecundity, batch fecundity and oocyte size of ripening ovaries of Pacific sardine Sardinops sagax in northern Chile. Fisheries Science 68, 95-103. doi:10.1046/J.1444-2906.2002.00394.X

Plaza, G., Honda, H., Sakaji, H., and Nashida, K. (2005). Preparing fish sagittae for examination of daily growth increments of young-of-theyear fishes: a modification of the embed method. Journal of Fish Biology 66, 592-597. doi:10.1111/J.0022-1112.2005.00625.X

Raventós, N., and Macpherson, E. (2001). Planktonic larval duration and settlement marks on otoliths of Mediterranean littoral fishes. Marine Biology 138, 1115-1120. doi:10.1007/S002270000535

Robert, D., Castonguay, M., and Fortier, L. (2007). Early growth and recruitment in Atlantic mackerel Scomber scombrus: discriminating the effects of fast growth and selection for fast grow. Marine Ecology Progress Series 337, 209-219. doi:10.3354/MEPS337209

Schreiber, M. A., and Halliday, A. (2013). Uncommon among the commons? Disentangling the sustainability of the Peruvian anchovy fishery. Ecology and Society 18, 1-15.

Shoji, J., and Tanaka, M. (2006). Growth-selective survival in piscivorous larvae of Japanese Spanish mackerel Scomberomorus niphonius: early selection and significance of ichthyoplankton prey supply. Marine Ecology Progress Series 321, 245-254. doi:10.3354/MEPS321245

Sirois, P., and Dodson, J. J. (2000). Critical periods and growth-dependent survival of larvae of an estuarine fish, the rainbow smelt Osmerus mordax. Marine Ecology Progress Series 203, 233-245. doi:10.3354/ MEPS203233

Somers, I. F. (1988). On a seasonally oscillating growth function. Fish Byte 6(1), 8-11.

Sparre, P., Ursin, E., and Venema, S. C. (1998). Introduction to Tropical Fish Assessment. Part 1: Manual. FAO Fisheries Technical Paper 306/1 Rev. 2. FAO, Rome.

Sponaugle, S. (2010). Otolith microstructure reveals ecological and oceanographic processes important to ecosystem-based management. Environmental Biology of Fishes 89, 221-238. doi:10.1007/S10641010-9676-Z

Summerfelt, R. C., and Hall, G. E. (Eds) (1987). 'Age and Growth of Fish.' (Iowa State University Press: Ames, IA, USA.)
Takahashi, M., and Watanabe, Y. (2004). Staging larval and early juveniles Japanese anchovy based on the degree of guanine deposition. Journal of Fish Biology 64, 262-267. doi:10.1111/J.1095-8649.2004.00283.X

Takahashi, M., Kinoshita, T., and Watanabe, C. (2001). Growth of larval and early juvenile Japanese anchovy, Engraulis japonicus, in the KuroshioOyashio transition region. Fisheries Oceanography 10, 235-247. doi:10.1046/J.1365-2419.2001.00160.X

Takahashi, M., Sassa, C., and Tsukamoto, Y. (2012). Growth-selective survival of young jack mackerel Trachurus japonicus during transition from pelagic to demersal habitats in the East China Sea. Marine Biology 159, 2675-2685. doi:10.1007/S00227-012-2025-3

Takasuka, A., Aoki, I., and Mitani, I. (2004). Three synergistic growthrelated mechanisms in the short-term survival of larval Japanese anchovy Engraulis japonicus in Sagami Bay. Marine Ecology Progress Series 270, 217-228. doi:10.3354/MEPS270217

Tanabe, T., Kayama, S., Ogura, M., and Tanaka, S. (2003). Daily increment formation in otoliths of juvenile skipjack tuna Katsuwonus pelamis. Fisheries Science 69, 731-737. doi:10.1046/J.1444-2906.2003.00680.X

Thiel, M., Macaya, E. C., Acuña, E., Arntz, W. E., Bastias, H., Brokordt, K., Camus, P. A., Castilla, J. C., Castro, L. R., Cortés, M., Dumont, C. P., Escribano, R., Fernandez, M., Gajardo, J. A., Gaymer, C. F., Gómez, I., González, A. E., González, H. E., Haye, P. A., Illanes, J. H., Iriarte, J. L., Lancellotti, D. A., Luna-Jorquera, G., Luxoro, C., Manriquez, P. H., Marín, V., Muñoz, P., Navarrete, S. A., Pérez, E., Poulin, E., Sellanes, J., Sepúlveda, H. H., Stotz, W., Tala, F., Thomas, A., Vargas, C. A., Vasquez, J. A., and Vega, A. (2007). The Humboldt Current System of northern and central Chile: oceanographic processes, ecological interactions and socioeconomic feedback. Oceanography and Marine Biology - an Annual Review 45, 195-344. doi:10.1201/ 9781420050943.CH6

Thorrold, R. S., and Williams, M. C. B. (1989). Analysis of otolith microstructure to determine growth histories in larval cohorts of a tropical herring (Herklotsichthys castelnaui). Canadian Journal of Fisheries and Aquatic Sciences 46, 1615-1624. doi:10.1139/F89-206

Victor, B. C. (1986). Duration of the planktonic larval stage of one hundred species of Pacific and Atlantic wrasses (family Labridae). Marine Biology 90, 317-326. doi:10.1007/BF00428555

von Bertalanffy, L. (1938). A quantitative theory of organic growth (inquiries on growth laws II). Human Biology 10, 181-213.

Waldron, M. E. (1994). Validation of annuli of the South African anchovy, Engraulis capensis, using daily otolith growth increments. ICES Journal of Marine Science 51, 233-234. doi:10.1006/JMSC.1994.1022

Waldron, M., and Kerstan, M. (2001). Age validation in horse mackerel (Trachurus trachurus) otoliths. ICES Journal of Marine Science 58, 806-813. doi:10.1006/JMSC.2001.1071

Wellington, G. M., and Victor, B. C. (1989). Planktonic larval duration of one hundred species of Pacific and Atlantic damselfishes (Pomacentridae). Marine Biology 101, 557-567. doi:10.1007/BF00541659

Wilson, D. T., and McCormick, M. I. (1997). Spatial and temporal settlement-marks in otoliths of tropical reef fishes. Marine Ecology Progress Series 153, 259-271. doi:10.3354/MEPS153259

Wright, P. J., Woodroffe, D. A., Gibb, F. M., and Gordon, J. D. M. (2002). Verification of first annulus formation in the illicia and otoliths of white anglerfish, Lophius piscatorius, using otolith microstructure. ICES Journal of Marine Science 59, 587-593. doi:10.1006/JMSC.2002.1179 